\title{
The Effect of Compensation and Motivation on Employee Performance: Study on Employees of Bank Jabar Banten Syariah Bandung City Branch
}

\author{
Lilis Sulastri \\ UIN Sunan Gunung Djati, Bandung, Indonesia \\ Email: lilis.sulastri@uinsgd.ac.id
}

\begin{abstract}
To assess the impact of remuneration and work incentive indicators on employee performance at Bank Jabar Banten Syariah Bandung. Applicant's name: The saturated sample method was used to choose 50 Bank Jabar Banten Syariah Bandung workers. Data analysis utilizing various linear approaches. Using the SPSS 26 program. The results showed that the two variables evaluated had a favorable effect in part. Compensation $\left(X_{1}\right)$ has a t count $>t$ table of $4.644>1.678$, with a significance of $0.000<0.05$. And a 0.546 coefficient. Motivation $\left(\mathrm{X}_{2}\right)$ has a t count $>t$ table of $4.901>1.678$ and a significance of 0.000 $<0.05$. And a 0.545 coefficient. Employee performance is affected by both salary and motivation at Bank Jabar Banten Syariah Bandung. Using $\mathrm{F}$ count and $\mathrm{F}$ table, the result is $10.322>3.20$. Compensation $\left(X_{1}\right)$ and Motivation $\left(X_{2}\right)$ have significance values of $0.000<$ 0.05 . Overall, salary and motivation have a considerable impact on employee performance. The examination of the coefficient of determination yielded 63.7 percent. That is, compensation and motivation affect 63.7 percent of their performance. Variables not addressed in this study explain the remaining 36.3 percent.
\end{abstract}

Keywords: Compensation, Motivation, Employee Performance.

\section{A. INTRODUCTION}

Management is the activity of having someone or a group carry out an action or training in order to make things better for the future. To obtain the desired result, an effective and efficient strategy must be used (Harahap, 2017). Among the many management derivatives is human resource management (HRM), which is a process of structuring and staffing an organization in order to fulfill organizational goals. HRM also includes developing and compensating employees in order to maintain and separate them from the organization (Suripto, 2016). However, it can also be interpreted as a system consisting of inter-dependent (continuous) activities. For example, how to lead can lead to inappropriate decisions, and so on if HR activities are appropriately involved and professionally in action (Tjahjono, 2005).

In an organization, human resources play a crucial role. As well as the good and bad of the organization depend on whoever fills the organization's container, and it can be in institutions, or agencies, or companies (Dehotman, 2016). Why is it like that? This HR is a goal for all activities in the company's final target. HR has a role in the planning process, implementation to the evaluation stage of all activities in the company (Purnawanto, 2010). Therefore, companies need human resources to manage 
and implement everything to fit the planned plan or become a vision and mission of the company (Mulyana, 2010).

Hasibuan (2012), HR management is the science and art of managing a relationship and the role of the workforce so that it is more organized to achieve a community, employee, organization, or company goal. HRM can be described in the form of science in which there is a human figure who is a potential resource that is very determined in the sustainability of a company. It must also be cultivated to contribute dominantly to a company or individual (Sunarsi, 2019). Management must be more influential in terms of the concept being prioritized in all activities, especially organizations where there is planning, management, control, and evaluation in an organization or company in HR in achieving a vision and mission direction of an organization or company (Suwatno \& Priansa, 2014).

Martoyo (2000) said that the ideal compensation could increase the motivation of employees because this can motivate employees to be more productive at work. Motivation has a driving force and enthusiasm for work and rules, then to increase desire and develop it must be with a strong will from everyone (Gultom, 2015). Motivation has value when you want to get a spirit at work or a spirit at work; motivation is a reference so that it can revive the employee's work spirit to work on the job as well as its mandate, so compensation and motivation are ingredients for increasing employee performance (Assagaf \& Dotulong, 2015).

The researcher hopes to discover anything new in this follow-up study, which will focus on the impact of salary and motivation on employee performance. The study was done at the Bandung branch of Bank Jabar Banten Syariah. My curiosity is piqued about the Bank Jabar Banten Syariah Bandung branch's compensation and motivation for employee success. Several employees of Bank BJB Syariah Bandung branch were interviewed directly by researchers to support the researcher's claim that salary and motivation affect employee performance. This led to a dispute.

\section{B. LITERATURE REVIEW}

\section{Human Resource Management}

According to George R. Terry (2008), management is born by processing specific actions such as planning, organizing, mobilizing, and controlling. The determination is made to achieve the goals or targets that have been set through the use of HR with other resources. When Hasibuan (2012) defines HRM, he means the process of coordinating and managing the activities of procuring goods and services and compensating people in order to achieve business as well as individual and community goals. The findings reveal that HRM is a form of management that involves strategizing, coordinating, and monitoring the various aspects of putting the fight on the field and participating in it in general.

\section{Compensation}

Compensation is an income in the form of money, goods directly or indirectly that employees can obtain because of the effort they have presented to the company 
(Muljani, 2002). Compensation in the form of money is a salary paid using money directed to employees. Compensation is in the condition of objects, namely wages paid by entities (Hasibuan 2012.) Compensation is another word related to financial rewards obtained by individuals through their employment relationship with the organization (Leonardo, 2015). The purpose of providing compensation is a cooperative bond by providing compensation to establish a formal coalition contract between superiors and subordinates. Managers must provide compensation according to the agreed-upon arrangement, while subordinates must do their jobs well employees will fulfill their physical and social needs, as well as logistical requirements in order to obtain job satisfaction from their position if they are paid well. To make procurement work, it must have a large enough compensation program so that hiring qualified people is not difficult.

\section{Motivation}

Understanding Motivation is a form of encouragement, desire or a considerable interest in oneself to achieve passion, ideals, and dreams. The birth of motivation is a reference for everyone to improve their quality day by day for their life goals. Maslow's theory suggests that individuals will generally have attitudes to awaken their lives in the concept of self-sufficiency. You tend to be prioritized. Then he must fulfill the $2 \mathrm{nd}$, $3 \mathrm{rd}$, and so on. This method will continue to be repeated to determine life priorities (Neher, 1991).

\section{Employee Performance}

Performance is a person's overall result or success during a specific task time as compared to previously set and agreed-upon work standards, targets, or criteria (Rivai, 2004). For Rivai, job happiness and compensation are determined by skills, abilities, and personal attributes, not only performance. To put it another way, employee productivity is influenced by three factors: power, desire, and the surrounding environment. The performance of each employee is influenced by a number of different characteristics. Companies require high-achieving personnel more than ever in today's competitive and globalized world. An objective performance evaluation will give you the information you need to make changes in your behavior that will lead to greater productivity and the results you want (Ruky, 2002). An objective and systematic procedure for gathering, analyzing, and using information to determine the efficiency and effectiveness of employee activities and the attainment of goals is performance appraisal, which can take numerous forms such as key performance indicator or key performance index. Employee performance evaluation depends on knowing what knowledge and abilities are required to conduct a competent job as well as a more in-depth investigation of personal characteristics.

\section{METHOD}

This study employs a quantitative descriptive method, and as a result, this research employs a quantitative methodology. To summarize, quantitative research 
methods are defined as those whose nature can be calculated using statistical methods, according to Sugiyono (2016). Data collection and analysis are quantitative/statistical in nature with the goal of testing hypotheses. Quantitative research methods can also be defined as research methods that are based on the philosophy of positivism and are used to examine specific populations or samples. Sampling techniques are generally carried out randomly, data collection is done with research instruments, and data analysis is quantitative/statistical in nature with the goal of testing hypotheses. Everything is already in place. There were 50 employees at the Bank Bjb Syariah Bandung branch that participated in this study, and 50 samples were drawn from this population using the saturated sample approach, which was used in this investigation. The researchers employed several linear analytic approaches with the assistance of the SPSS version 26 software in order to resolve the issues raised by this study applicability.

\section{RESULT AND DISCUSSION}

\section{Data Validity Test}

A measuring instrument's validity, according to Husein Umar (2011), demonstrates how well it measures what it is supposed to. A questionnaire is considered valid if the questions on it provide information that the questionnaire will assess. There are 50 participants that will take part in this validity test. A valid instrument is one that is capable of providing accurate results from the variables being researched when it is being used. The SPSS program is used to carry out validity testing, and the test criteria are as follows: The sentence is true if $r$ count $>r$ table. The sentence isn't valid if $r$ count is less than $r$ table. With $N=50$ respondents and a researcher error level of $5 \%$, we can arrive at an answer with a $r$ value of critical significance $=0.285$. It's safe to say that all items on this questionnaire are valid based on the measurement results using SPSS for the variables Compensation (X1), Motivation (X2), and Employee Performance (Y).

\section{Reliability Test}

Reliability is a method used to test a questionnaire's ability to identify a variable or set of variables. If a person's answer to a question is consistent or stable throughout time, a questionnaire is considered dependable. Cronbach's alpha statistical test for reliability in making decisions the value of $\mathrm{r}$ alpha is compared to a value of 0.60 to establish the variable's significance. If the $r$ alpha value is more than 0.60 , the variables being examined are trustworthy. The SPSS 26 calculation method was used to assess the instrument's dependability. The SPSS output shows what is seen as Cronbach Alpha $0.817>0.60$. All the questions/statements constructs, which are the dimensions of the 3 variables, are reliable.

\section{Multiple Linear Regression Test}

When two or more independent variables ("X1, X2") are analyzed, the results show a linear connection with the dependent variable (Y). SPSS version 26.0 is used to 
perform this analysis, which determines whether each independent variable is positively or negatively correlated, and then predicts whether the dependent variable's value will increase or decrease if its value rises or declines.

Table 1 Multiple Linear Regression Test Results

\section{Coefficients $^{a}$}

\begin{tabular}{|l|r|r|}
\hline \multirow{2}{*}{ Model } & \multicolumn{2}{|c|}{$\begin{array}{c}\text { Unstandardized } \\
\text { Coefficients }\end{array}$} \\
\cline { 2 - 3 } (Constant) & \multicolumn{1}{|c|}{ B } & Std. Error \\
Compensation $(X 1)$ & 1.288 & 2.905 \\
Motivation (X2) & .546 & .068 \\
\hline
\end{tabular}

a. Dependent Variable: Performance $(Y)$

Based on table 1 above, the following multiple linear regression equation is obtained: $\mathrm{Y}=\mathbf{1 . 2 8 8}+\mathbf{0 . 5 4 6 X 1}+\mathbf{0 . 5 4 5 X 2}$. From the multiple linear regression equation above, it can be interpreted as follows:

a. The constant value has a positive value of 1.288 ; if the value of the compensation and work motivation variables is considered fixed and has a value of zero, then the employee's performance still has a positive value.

b. Compensation has a positive impact on employee performance, as seen by the variable's unstandardized coefficients (B), which have a positive value of 0.546. The performance of employees at the Bank BJB Syariah Bandung Branch will rise in response to an increase in the pay variable.

c. X2 (work motivation) has a positive value of 0.545 for the unstandardized coefficients (B), indicating a positive relationship between work motivation and employee performance. Employees at the Bank BJB Syariah Bandung Branch will perform better if the work motivation variable rises.

\section{Hypothesis Testing}

Hypothesis is a short-term solution to the initial framing of the study challenge. Evidence for this hypothesis must be gathered from many sources. In statistics, the hypothesis is described as a query regarding the population's status (Parameters) that will be investigated to see if it is true using data from the research sample (Sugiyono, 2016).

\section{T-Test (Partial)}

Table 2 t-test Results

Coefficients $^{\mathrm{a}}$

\begin{tabular}{|c|c|c|c|c|c|}
\hline \multirow[b]{2}{*}{ Model } & \multicolumn{2}{|c|}{$\begin{array}{l}\text { Unstandardized } \\
\text { Coefficients }\end{array}$} & \multirow{2}{*}{$\begin{array}{c}\begin{array}{c}\text { Standardized } \\
\text { Coefficients }\end{array} \\
\text { Beta } \\
\end{array}$} & \multirow[b]{2}{*}{$t$} & \multirow[b]{2}{*}{ sig } \\
\hline & B & Std. Error & & & \\
\hline (Constant) & 1.288 & 2.905 & & .443 & .659 \\
\hline Compensation (X1) & .546 & .068 & .534 & 4.644 & .000 \\
\hline Motivation (X2) & .545 & .130 & .198 & 4.901 & .000 \\
\hline
\end{tabular}

a. Dependent Variable: Performance (Y) 
Based on table 1, it is discovered that the value of the t-test results for the compensation variable (X1) is obtained; the $\mathrm{t}$-count is $4.375>\mathrm{t}$-table is 1.678 with a Sig value of $0.000>0.05$. The t-test results indicate that the compensation variable (X1) influences employee performance $(\mathrm{Y})$. As a result, the hypothesis is tested in such a way that Ha is accepted and Ho is rejected. The t-test results for the work motivation variable (X2) were obtained at a count value of $2.624>t$ table 1.678 and a Sig value of 0.05 . The t-test results indicate that the work motivation variable $(X 2)$ influences employee performance $(\mathrm{Y})$. As a result, the hypothesis testing form $\mathrm{Ha}$ is accepted. As a result, Ha is accepted and Ho is rejected in the form of hypothesis testing.

\section{F Test (Simultaneous)}

The $\mathrm{F}$ test is used to determine the strength of the relationship between the independent and dependent variables. Following Kuncoro (2001), the initial F test reveals that all independent variables, regardless of whether they are part of the model, have a significant impact on some variables. Use the F test to see if two independent variables have any effect on one another.

Table F Test Results

ANOVA

\begin{tabular}{|l|r|r|r|l|l|}
\hline Model & Sum of Square & df & Mean Square & F & Sig \\
\hline Regression & 45.931 & 2 & 22.966 & 10.322 & $.000^{\mathrm{a}}$ \\
Residual & 104.569 & 48 & 2.225 & & \\
Total & 150.500 & 50 & & & \\
\hline
\end{tabular}

a. Predictor: (Constant), Motivation (X2), Compensation (X1)

b. Dependent variable: Performance $(\mathrm{Y})$.

They compute the results. 10.322 is the value displayed for F. F count $3.20>$ F table 10.322 with a Sig F value less than 5 percent to put it another way, the compensation variable affects employee performance simultaneously or combined with work motivation (Y). Independent variables have an impact on dependent variables when significant (0.05). The findings of this $\mathrm{F}$ test show that compensation and work motivation together have an impact on the performance of Bank BJB Syariah Bandung branch employees, hence the hypothesis testing method of Ha is approved as a valid approach.

\section{Test the Coefficient of Determination R2}

$\mathrm{R} 2$ is a measure of how well a model is able to explain the variation in the dependent variable, according to Ghozali (2012). The correlation coefficient ranges from 0 to 1 . If R2 is low, the independent variables' ability to explain the dependent variable's variation is severely hampered. However, if a score close to the independent variables offers nearly all of the information needed, it will be able to forecast the dividend variables as well. 
Table 4 Test of the coefficient of determination

Model Summary

\begin{tabular}{|l|c|r|r|r|}
\hline Model & R & R Square & $\begin{array}{r}\text { Adjusted } \\
\text { R Square }\end{array}$ & $\begin{array}{c}\text { Std. Error of } \\
\text { Estimate }\end{array}$ \\
\hline 1 & .798 & .637 & .276 & 1.49160 \\
\hline
\end{tabular}

Predictors: (Constant), motivation, compensation

Table 4 shows the $\mathrm{R}$ Square is 0.305 , according to the data. According to the results, the independent variables utilized in this study model account for $63.7 \%$ of the variance in how well Bank BJB Syariah Bandung Branch employees perform. Other variables not included in this research have an impact on the remaining $36.3 \%$ of the sample.

\section{Discussion}

Employee performance is positively impacted by pay (X1) (Y). The t-test (partial) shows that $\mathrm{t}$ count $>\mathrm{t}$ table has a value of $4.644>1.678$, rejecting $\mathrm{H} 0$ and accepting $\mathrm{Ha}$, and a 0.546 positive correlation. This suggests that employee performance is influenced by compensation (X1) to some extent (Y). Based on a 0.000 $<0.05$ significance value, Compensation $(\mathrm{X} 1)$ has a significant impact on employee performance (Y). In keeping with past studies, such as that done by Astuti (2019), remuneration variables do have an effect on employee performance variables in reality.

The research results that have been carried out show that the compensation for employees of the BJB Syariah bank in the City of Bandung is included in the reasonably good category. This can be seen from the level of suitability of basic salary, incentive money, food allowance, transportation allowance, THR, and health insurance coverage which, according to employees, is entirely appropriate to meet the needs of employees every month. This shows that the Compensation of BJB Syariah bank employees in Bandung City is quite good. It impacts employee performance which can also be seen from the results of the effect of compensation on employee performance.

In terms of employee performance, motivation $(\mathrm{X} 2)$ is positively and significantly related ( $\mathrm{Y}$ ). To summarize, $\mathrm{H} 0$ is rejected and $\mathrm{Ha}$ is approved by the $\mathrm{t}$ test (partial) because of the higher value of $t$ count $>t$ table $(4.901>1.678)$. The correlation is also favorable, coming in at 0.545. Motivating employees (X2) has a favorable effect on their performance to some extent (Y). Motivating Employees (X2) is significant to Employee Performance since its significance value is $0.000<0.05$. (Y). Damayanti \& Sumaryati (2013) conducted previous study and found that job motivation influences employee performance. This finding is in line with their findings.

Employee performance is significantly influenced by both compensation (X1) and motivation (X2), both occurring at the same time (Y). Given that F count $>\mathrm{F}$ table has a value of $10.322>3.20$ (simultaneous test), H0 is refused and Ha is approved (as shown by the $\mathrm{F}$ test). Compensation (X1) and incentive (X2) have an impact on 
employee performance concurrently, then (Y). Compensation (X1) and Motivation $(\mathrm{X} 2)$ have a significance value of $0.000<0.05$, indicating that both are important for employee performance (Y). Compensation (X1) and Motivation (X2) have a 63.7 percent effect on Employee Performance (Y), indicating a strong link. Employee productivity will rise if they receive fair compensation and are motivated to do their best work. If these three components work together harmoniously, errors in work can be reduced to a bare minimum, resulting in better job outcomes. The quality and quantity of employee work can meet or exceed company expectations if employees perform well. A study by Kasenda (2013) has found that salary and motivation affect employee performance in a positive and significant way.

\section{E. CONCLUSION}

It is possible, based on the findings of the research, that compensation has a considerable and favorable impact on the performance of Bank BJB Syariah Bandung branch employees. Whether or whether employees are paid fairly has an impact on their productivity. Similar to motivation, employee performance is positively impacted to some extent by it. Good work motivation makes employee performance and company performance increase and can help companies achieve their targets. Finally, competence and motivation simultaneously affect the performance of bank employees BJB Syariah Bandung branch.

\section{REFERENCES}

1. Assagaf, S. C. Y., \& Dotulong, L. O. (2015). Pengaruh Disiplin, motivasi dan semangat kerja terhadap produktivitas kerja pegawai dinas pendapatan daerah kota manado. Jurnal EMBA: Jurnal Riset Ekonomi, Manajemen, Bisnis dan Akuntansi, 3(2).

2. Dehotman, K. (2016). Pengaruh Pendidikan Terhadap Kinerja Karyawan Baitul Mal Wat-Tamwil di Provinsi Riau. JEBI (Jurnal Ekonomi dan Bisnis Islam), 1(2), 217234.

3. Ghozali, I. (2016). Aplikasi Analisis Multivariate dengan Program IBM SPSS 23. Semarang: Universitas Diponegoro Press.

4. Gultom, D. K. (2015). Pengaruh budaya organisasi perusahaan dan motivasi terhadap kinerja karyawan pada PT. Perusahaan Gas Negara (Persero) Tbk Medan. Jurnal Ilmiah Manajemen dan Bisnis, 14(2).

5. Harahap, S. (2017). Implementasi Manajemen Syariah Dalam Fungsi-Fungsi Manajemen. AT-TAWASSUTH: Jurnal Ekonomi Islam, 2(1), 211-234.

6. Hasibuan, M. S. (2012). Manajemen SDM. Revised Edition, Thirteenth Printing. Jakarta: Bumi Aksara.

7. Husein, U. (2011). Metode Penelitian Untuk Skripsi dan Tesis Bisnis. Jakarta: Raja Grafindo Persada.

8. Leonardo, E. (2015). Pengaruh Pemberian Kompensasi Terhadap Kinerja Karyawan pada PT. Kopanitia. Agora, 3(2), 28-31. 
9. Mangkunegara, A. A. P. (2011). Manajemen Sumber Daya Manusia Perusahaan. Bandung: Remaja Rosdakarya.

10. Martoyo, S. (2000). Manajemen Sumber Daya Manusia. Yogyakarta: BPFE.

11. Muljani, N. (2002). Kompensasi Sebagai Motivator Untuk Meningkatkan Kinerja Karyawan. Jurnal Manajemen dan Kewirausahaan, 4(2), 108-122.

12. Mulyana, M. (2010). Manajemen Sumber Daya Manusia (SDM) Ritel Dalam Meningkatkan Kinerja Perusahaan. Jurnal Ilmiah Ranggagading, 10(2), 164-170.

13. Neher, A. (1991). Maslow's Theory of Motivation: A Critique. Journal of Humanistic Psychology, 31(3), 89-112.

14. Purnawanto, B. (2010). Manajemen SDM Berbasis Proses. Grasindo.

15. Rivai, V. (2004). Manajemen Sumber Daya Manusia untuk Perusahaan Dari Teori ke Praktek. Jakarta: Grafindo Persada.

16. Ruky, A. S. (2002). Sistem Manajemen Kinerja. Gramedia Pustaka Utama.

17. Sugiyono. (2016). Metode Penelitian Kuantitatif, Kualitatif dan RED. Bandung: Alfabeta.

18. Sunarsi, D. (2019). Penerapan MSDM Strategis Dalam Upaya Meningkatkan Kemampuan Organisasi dalam menyongsong Revolusi 4.0. Jurnal Ilmiah MEA (Manajemen, Ekonomi, \& Akuntansi), 3(1), 221-233.

19. Suripto, T. (2016). Manajemen SDM Dalam Prespektif Ekonomi Islam: Tinjauan Manajemen Sdm Dalam Industri Bisnis. JESI (Jurnal Ekonomi Syariah Indonesia), 2(2), 239-250.

20. Suwatno, H. D., \& Priansa, D. J. (2014). Manajemen SDM dalam organisasi Publik dan Bisnis. Bandung: Alfabeta.

21. Terry, G. R. (2008). Prinsip-Prinsip Manajemen. Jakarta: Bumi Aksara.

22. Tjahjono, H. K. (2005). Praktik-praktik Manajemen SDM Strategik: Pengujian Empiris Universalistik dan Kontinjensi dalam Menjelaskan Kinerja Organisasional. Kinerja Journal of Business and Economics, 9(2), 123-134. 